\title{
Surveillance Data Highlights Feed Form, Biosecurity, and Disease Control as Significant Factors Associated with Salmonella Infection on Farrow-to-Finish Pig Farms
}

\author{
Hector Argüello ${ }^{1 *}$, Edgar G. Manzanilla ${ }^{2}$, Helen Lynch ${ }^{1,3}$, Kavita Walia ${ }^{1,4}$, \\ Finola C. Leonard ${ }^{3}$, John Egan ${ }^{4}$, Geraldine Duffy ${ }^{1}$, Gillian E. Gardiner ${ }^{5}$ and \\ Peadar G. Lawlor ${ }^{2}$ \\ ${ }^{1}$ Teagasc, Food Research Centre, Ashtown, Ireland, ${ }^{2}$ Pig Development Department, Animal and Grassland Research and \\ Innovation Centre, Teagasc, Fermoy, Ireland, ${ }^{3}$ School of Veterinary Medicine, University College Dublin, Dublin, Ireland, \\ ${ }^{4}$ Central Veterinary Research Laboratory, Department of Agriculture, Food and the Marine, Backweston, Ireland, \\ ${ }^{5}$ Department of Science, Waterford Institute of Technology, Waterford, Ireland
}

OPEN ACCESS

Edited by:

David Rodriguez-Lazaro, University of Burgos, Spain

Reviewed by:

Dario De Medici,

Istituto Superiore di Sanità, Italy

Francisco Diez-Gonzalez,

University of Georgia, United States

*Correspondence:

Hector Argüello

arguello.rguez@gmail.com

Specialty section:

This article was submitted to

Food Microbiology,

a section of the journal

Frontiers in Microbiology

Received: 12 November 2017

Accepted: 26 January 2018

Published: 15 February 2018

Citation:

Argüello $H$, Manzanilla EG, Lynch $H$, Walia K, Leonard FC, Egan J, Duffy G,

Gardiner GE and Lawlor PG (2018)

Surveillance Data Highlights Feed

Form, Biosecurity, and Disease

Control as Significant Factors Associated with Salmonella Infection

on Farrow-to-Finish Pig Farms.

Front. Microbiol. 9:187.

doi: 10.3389/fmicb.2018.00187
Among the zoonotic pathogens affecting pigs, Salmonella stands out due to the high number of human cases linked to pork consumption. In the last two decades many countries have put considerable effort into the control of the infection by surveillance and control strategies on farm. Despite this effort, many herds still have a high Salmonella prevalence and they require guidance to address this problem. The present study, using the serological surveillance data of finishing pigs from the Irish National pig Salmonella Control Programme, aimed to highlight factors associated with increased risk or that might mitigate Salmonella occurrence on farm. A questionnaire with 33 questions regarding herd characteristics, management, feeding, biosecurity, and health was completed for 61 individual herds. After the multivariate analysis by linear regression, nine variables were retained in the final model and linked to herd seroprevalence. Home produced-feed linked to the use of meal showed an eight points reduction in Salmonella prevalence compared to purchased feed $(p=0.042)$. Different biosecurity measures were associated to lower seroprevalence. Changing of footwear from outside to inside the farm decreased seroprevalence nearly 20 units $(p=0.014)$ and policies not permitting access to the farmyard to feed trucks $(p=0.048)$ or avoiding the presence of cats on the farm $(p=0.05)$ were estimated in 10 units less of seroprevalence. In contrast, the lack of perimeter fence increased the chance to have higher seroprevalence in five units $(p=0.05)$. Finally, intestinal diseases such as swine dysentery $(p=0.044)$ and $E$. coli diarrhea $(p=0.1)$ were estimated to increase Salmonella prevalence in $\sim 20$ and 10 units, respectively, demonstrating the importance of controlling other enteric pathogens in an on-farm Salmonella control programme. These results show the usefulness of surveillance data to improve on-farm control and confirm that Salmonella infection in pigs is multi-factorial and the approach to its control should be multifaceted.

Keywords: control, foodborne-pathogen, risk factors, feed, swine dysentery, biosecurity 


\section{INTRODUCTION}

Among food-borne pathogens in the EU, Salmonella ranks second in the number of human cases, after Campylobacter spp., and is responsible for the highest number of food-borne outbreaks (EFSA, 2015). Pork is one of the main sources of human salmonellosis cases and following the successful implementation of control programmes in poultry, the relative proportion of salmonellosis cases attributed to pork consumption has risen (De Knegt et al., 2015).

Many countries, including Ireland, have surveillance and control programmes in operation which aim to reduce the risk of Salmonella transmission in the pig production chain (Quirke et al., 2001; Stärk et al., 2002; Alban et al., 2012). The Irish National Pig Salmonella Control Programme (NPSCP) commenced in 2002 and was revised in 2010 with the aim of reducing Salmonella prevalence in the pork production chain. Similar to other on farm control programmes (Alban et al., 2012) the NPSCP collects sera (six samples per month) from each herd and the prevalence is estimated considering the results from the last 3 months using a weighting of 3:1:1 with the results from the most recent month having the highest weighting. All herds with a prevalence value over $50 \%$ are categorized as high risk and are required to put control measures in place.

On farm control includes potential strategies such as the use of vaccines (Arguello et al., 2013b), organic acids (Arguello et al., 2013a; Walia et al., 2016) and many other potential actions related to husbandry, management, hygiene, biosecurity, and feed (De Busser et al., 2013; De Ridder et al., 2013; Burns et al., 2015). Risk factor studies help to determine which on farm actions may be most effective in reducing on farm prevalence as well as identifying factors likely to increase the risk of having Salmonella in the herd. A number of studies to identify such on-farm factors have been performed either using bacteriology (van der Wolf et al., 2001a; Lo Fo Wong et al., 2004; GarcíaFeliz et al., 2009; Correia-Gomes et al., 2012, 2013), or serology (van der Wolf et al., 2001b; Beloeil et al., 2007; Smith et al., 2010). Interestingly factors related to management such as allin/all-out policy (AI/AO), hygiene, presence of other diseases such as Porcine respiratory and reproductive syndrome (PRRS) and particularly factors associated with feed (coarseness, meal vs. pelleted, home-produced vs. purchased) have been associated with infection, but results are not always consistent across studies, while findings on the effect of factors such as herd size, cleaning protocols, and antimicrobial usage are disputed. These differences may be related to the outcome variable (bacteriology or serology), the type of study (cross-sectional or cohort studies) and even to the serotype or serotypes involved in the infection (Correia-Gomes et al., 2012). Despite the effort, inconsistent results require more research to clarify how to mitigate the on farm Salmonella burden. Data from surveillance programmes such as the Irish NPSCP is extremely useful in performing epidemiological studies (Baptista et al., 2010; Smith et al., 2010). The aim of the present study was to provide new insights regarding on farm practices related to herd characteristics management, husbandry, feeding, biosecurity and diseases, that affect the herd Salmonella prevalence by the analysis of data from a farm questionnaire combined with serology data provided by the NPSCP.

\section{MATERIALS AND METHODS}

\section{Questionnaire Survey}

A cross-sectional study, using a questionnaire survey, was conducted to collect information from Irish herds which sold finisher pigs to the slaughterhouse. Only farrow-to-finish and finishing herds were included in the study as breeding herds (those selling weaner pigs) are not included in the surveillance performed by the NSPCP and the number of such herds is small in Ireland. The questionnaires were completed between October 2014 and May 2015 during workshops with farmers and visits to farms. The questionnaire was designed and tested prior to use in collaboration with Teagasc pig advisors and farm staff. The purpose of the study and instructions on how to complete the questionnaire were explained to the farmers. A cover letter was included with the questionnaire explaining the aim of the study, the confidentiality of the results, the importance of accuracy in filling out the questionnaire, and contact details to obtain clarifications if required. In total, 33 closed questions were posed regarding factors previously included in studies on risk factors for Salmonella and adapted to the particularities of pig production in Ireland. The questionnaire was divided into five sections or topics: with questions related to herd characteristics, herd management (Table 1) feed and water (Table 2), hygiene and biosecurity (Tables 1, 3), and herd health (Table 3).

\section{Salmonella Data Collection}

Meat-juice serological data from Irish herds selling finisher pigs to abattoirs, between January and December 2014, were obtained from the Department of Agriculture Food and the Marine (DAFM), institution responsible for the Irish National pig Salmonella Control Programme. Annual prevalence was estimated by dividing the number of positive pigs delivered to the slaughterhouse in 2014 by the total number of pigs sampled from the same herd during the same period. Salmonella serological data were matched to the questionnaire data using the national herd numbers provided in both databases.

\section{Detection of Salmonella (Serology)}

The detection of antibodies (IgG) in meat juice samples obtained from finishing pigs delivered to the slaughterhouse was performed by an indirect enzyme-linked immunosorbent assay (ELISA). In most cases, six pigs per herd were randomly selected at the slaughterhouse for sampling each month, although frequency of sampling varied occasionally subject to delivery of pigs to the abattoir. Meat juice samples consisted of $10 \mathrm{~g}$ of the intercostal muscle. Samples were submitted to the National Reference Laboratory where they were frozen and stored at $\sim-$ $20^{\circ} \mathrm{C}$ until analysis. Prior to analysis, each sample was thawed and the muscle fluid was then analyzed by an in-house ELISA based on the Danish mix-ELISA (Nielsen et al., 1998). The indirect ELISA used allows the detection of porcine IgG against the Ochain of the lipopolysaccharide from Salmonella serogroups B, $\mathrm{C} 1$, and D. Calibrated optical densities (OD\%) were obtained 
TABLE 1 | Description of variables associated to herd characteristics, herd management and biosecurity included in the questionnaire completed by 61 Irish herds.

\begin{tabular}{|c|c|c|}
\hline Variable & Categories & No. Herds (\%) ${ }^{a}$ \\
\hline \multicolumn{3}{|l|}{ HERD CHARACTERISTICS } \\
\hline Herd size & $\begin{array}{l}\text { Number of sows in } \\
\text { the herd }\end{array}$ & Continuous \\
\hline \multirow{3}{*}{$\begin{array}{l}\text { Other animal species in the } \\
\text { herd }\end{array}$} & No & $40(65.6)$ \\
\hline & Cattle & $21(34.4)$ \\
\hline & Sheep & $1(1.6)$ \\
\hline Full-time staff & $\begin{array}{l}\text { No. of people in } \\
\text { the herd }\end{array}$ & Continuous \\
\hline \multirow[t]{2}{*}{ Permanent staff } & Yes & $40(65.6)$ \\
\hline & No & $21(34.4)$ \\
\hline \multirow[t]{2}{*}{ Labor employed } & Yes & $42(68.9)$ \\
\hline & No & $19(31.1)$ \\
\hline \multirow[t]{2}{*}{ Specialized areas of work } & Yes & $42(68.9)$ \\
\hline & No & $19(31.1)$ \\
\hline \multirow[t]{2}{*}{ Training courses } & Yes & $32(52.5)$ \\
\hline & No & $29(47.5)$ \\
\hline \multirow{3}{*}{$\begin{array}{l}\text { Distribution of production } \\
\text { stages (Yes/No) }\end{array}$} & Weaning & $51(83.6) / 10(16.4)$ \\
\hline & Growing & $50(82) / 11(18)$ \\
\hline & Finishing divided & $13(21.3) / 48(78.7)$ \\
\hline \multicolumn{3}{|l|}{ HERD MANAGEMENT } \\
\hline \multirow[t]{3}{*}{ All-in/all-out policy (Yes/No) } & Farrowing & $48(78.7) / 13(21.3)$ \\
\hline & Weaning & $46(75.4) / 15(24.6)$ \\
\hline & Finishing & $34(55.7) / 27(44.3)$ \\
\hline \multirow[t]{3}{*}{ Pig regrouping (Yes/No) } & Weaning & $40(65.6) / 21(34.4)$ \\
\hline & Growing & $24(34.3) / 37(60.7)$ \\
\hline & Finishing & $22(36.1) / 39(63.9)$ \\
\hline \multicolumn{3}{|l|}{ BIOSECURITY MEASURES } \\
\hline \multirow{5}{*}{$\begin{array}{l}\text { Presence of farms within } \\
2 \mathrm{~km}\end{array}$} & Pigs & $15(24.6)$ \\
\hline & Cattle & $44(72.1)$ \\
\hline & Sheep & $14(22.9)$ \\
\hline & Others & $1(1.6)$ \\
\hline & No & $9(14.8)$ \\
\hline \multirow[t]{3}{*}{ Fence } & Single & $33(54.1)$ \\
\hline & Double & $8(13.1)$ \\
\hline & No & $20(32.8)$ \\
\hline \multirow{2}{*}{$\begin{array}{l}\text { Hygienic barrier at the } \\
\text { entrance }\end{array}$} & Yes & $11(18)$ \\
\hline & No & $50(81.2)$ \\
\hline \multirow[t]{2}{*}{ Loading bay at the entrance } & Inside & $46(75.4)$ \\
\hline & Outside & $14(22.9)$ \\
\hline \multirow[t]{2}{*}{ Access of the feed truck } & Inside & $13(21.3)$ \\
\hline & Outside & $48(78.7)$ \\
\hline \multirow{2}{*}{$\begin{array}{l}\text { Access of the disposal } \\
\text { carcass truck }\end{array}$} & Inside & $25(40.1)$ \\
\hline & Outside & $36(59)$ \\
\hline \multirow[t]{2}{*}{ Presence of changing room } & Yes & $47(81.1)$ \\
\hline & No & $11(18.9)$ \\
\hline \multirow[t]{4}{*}{ Hygiene and clothes for staff } & Hand washing & $52(85.2) / 9(14.8)$ \\
\hline & Shower & $36(70.6) / 15(29.4)$ \\
\hline & Clothes change & $44(72.1) / 17(27.9)$ \\
\hline & Boots change & $52(85.2) / 9(14.8)$ \\
\hline
\end{tabular}

(Continued)
TABLE 1 | Continued

\begin{tabular}{llc}
\hline Variable & Categories & No. Herds (\%) \\
\hline $\begin{array}{l}\text { Hygiene and clothes for } \\
\text { visitors }\end{array}$ & Hand washing & $47(77) / 14(13)$ \\
& Shower & $36(70.6) / 15(29.4)$ \\
& Clothes change & $46(75.4) / 15(24.6)$ \\
& Boots change & $51(83.6) / 10(16.4)$ \\
Policy of visitors (Yes/No) & Require visitors to & $30(49.2) / 31(50.8)$ \\
& be free of visiting & \\
Presence of animals on the & Bother farm ${ }^{b}$ & \\
farm (Yes/No) & Birds & $29(47.5) / 32(52.5)$ \\
& Rodents & $51(83.6) / 10(16.4)$ \\
& Cats & $22(36.1) / 39(63.9)$ \\
& Dogs & $18(29.5) / 43(71.5)$
\end{tabular}

${ }^{a}$ Not all questions were answered in all herds, thus not all questions sum 61 farms.

${ }^{b}$ Minimum of 3 days before visiting the herd.

by regression analyses of positive and negative reference sera. The meat-juice test was considered positive above a cut-off of 40 OD\%. According to Nielsen et al. (1998) the sensitivity of the test is $\sim 89-100 \%$ and the specificity is $98-100 \%$, at individual animal level.

\section{Statistical Analysis}

A database including information from questionnaires and the NPSCP was created using Excel (Microsoft Office). Any inconsistency in answers was discussed with farmers or Teagasc farm advisors and corrected if necessary. A total of 125 variables were created from the answers obtained in the questionnaire.

All statistical analysis was conducted using SAS 9.3 (Cary, $\mathrm{NC}$ ). As a first step, a descriptive analysis was performed to identify variables with a large number of missing observations or with low variability making them of little value for further investigation. After this validation step, a univariate analysis was conducted using the annual Salmonella herd prevalence as the outcome variable. A relaxed $P$-value $\leq 0.25$ was used to select variables for further analysis in a multivariable model. Collinearity was evaluated among pre-selected variables using chi-square and Fischer's tests. From the correlated variables the ones with the lowest $P$-value and/or that made most biological sense were selected for the final multivariable model. Multivariable analysis was performed using a stepwise selection. Variables were retained in the model when $p$-value was $<0.15$ while $\alpha=0.05$ was established as threshold for significance. Interactions were checked among all the variables in the model and introduced one by one to see if they would improve the fitness of the model. As well, all rejected variables were added separately into the final model to ensure no significant variables had been omitted. Two-way interactions were checked among all the variables in the model.

\section{RESULTS}

A total of 67 questionnaires were returned. Six of these were discarded due to the low number of samples tested for Salmonella 
TABLE 2 | Description of the feed variables generated from the questionnaire data completed in 61 Irish herds.

\begin{tabular}{|c|c|c|c|c|c|c|}
\hline Variable & Categories & Farm & Sow & Weaners & Growers & Finishers \\
\hline \multirow[t]{2}{*}{ Origin } & $\begin{array}{l}\text { Home- } \\
\text { made }\end{array}$ & - & - & 11 & 14 & 14 \\
\hline & Purchased & - & - & 48 & 43 & 47 \\
\hline \multirow[t]{5}{*}{ Type of feed } & Liquid & - & 4 & 1 & 5 & 4 \\
\hline & Meal & - & 30 & 19 & 22 & 30 \\
\hline & Pelleted & - & 23 & 37 & 30 & 27 \\
\hline & Dry & - & 24 & 30 & 18 & 17 \\
\hline & Wet & - & 27 & 23 & 32 & 37 \\
\hline \multirow{4}{*}{$\begin{array}{l}\text { Supplements } \\
\text { in feed }\end{array}$} & Antibiotics & - & - & $48 / 13$ & $8 / 53$ & $3 / 58$ \\
\hline & Zinc Oxide & - & - & $48 / 13$ & $26 / 34$ & $1 / 60$ \\
\hline & Acids & - & - & $9 / 52$ & $7 / 54$ & $8 / 53$ \\
\hline & Whey & - & - & $2 / 59$ & $2 / 59$ & $7 / 54$ \\
\hline \multirow[t]{4}{*}{ Water supply } & Bore hole & 46 & & & & \\
\hline & $\begin{array}{l}\text { Main } \\
\text { supply }\end{array}$ & 12 & & & & \\
\hline & River & 1 & & & & \\
\hline & Other & 2 & & & & \\
\hline \multirow{2}{*}{$\begin{array}{l}\text { Chlorinated } \\
\text { water }\end{array}$} & Yes & 8 & & & & \\
\hline & No & 53 & & & & \\
\hline \multirow[t]{3}{*}{ Type of water } & Soft & 9 & & & & \\
\hline & Hard & 42 & & & & \\
\hline & $\begin{array}{l}\text { Do not } \\
\text { known }\end{array}$ & 10 & & & & \\
\hline
\end{tabular}

sero-prevalence on these farms throughout 2014. Thus, 61 farms were used for further analysis. In these herds the number of samples analyzed in 2014 varied from 24 to 96, with a median of 72.0 tests analyzed per herd $(\mathrm{SE}=1.5)$. More than $95 \%$ of herds had at least 48 tests performed. The mean annual prevalence in 2014 was $25.4(\mathrm{SE}=2.4)$. There was no correlation between number of sera analyzed and herd prevalence $(r=0.031)$. Herd prevalence ranged from six herds completely negative in the analysis performed (prevalence $0 \%$ ) to a maximum prevalence of $79.2 \%$ in one herd. A total of 125 variables were derived from the questionnaire circulated to the farmers (Tables 1-3). Of the 61 farms included in the analysis, all but three were farrow-to-finish herds. The three non farrow-to-finish herds were finishing farms which purchased weaner pigs from specialist breeding herds. The mean number of sows per farrow-to-finish herd was 586 and the median was 410 sows/herd $(S D=511.7)$. The smallest herd in the study had 50 sows and only three of the herds included had $<100$ sows. There was no correlation between herd size and herd prevalence $(R=0.03)$.

A number of variables were removed due to the low variability exhibited in the descriptive analysis of the data. Low variability between herds (defined as $\leq 3$ herds in a category) was detected in variables such as type of herd, replacement policy (few herds purchased weaners and/or finishers), feed allocation (ad-libitum access to feed was provided in all the herds) and the use of antimicrobials or pharmacological levels of zinc oxide in finisher feed (not practized in most herds). Thirty-five variables were
TABLE 3 | Health and cleaning variables included in the questionnaire data completed in 61 Irish herds ${ }^{a}$

\begin{tabular}{|c|c|c|c|}
\hline Disease & $\begin{array}{l}\text { No. herds } \\
\text { present (\%) }\end{array}$ & $\begin{array}{l}\text { No. herds } \\
\text { free }(\%)\end{array}$ & $\begin{array}{c}\text { No. herds } \\
\text { unknown (\%) }\end{array}$ \\
\hline \multicolumn{4}{|l|}{ HEALTH } \\
\hline $\mathrm{PRRS}^{\mathrm{b}}$ & $29(47.5)$ & $29(47.5)$ & $3(5)$ \\
\hline Pleuropneumonia (APP) & $20(32.8)$ & $25(40.1)$ & $16(26.2)$ \\
\hline Enzootic pneumonia & $25(40.1)$ & $19(31.1)$ & $17(27.8)$ \\
\hline Glasser & $10(16.4)$ & $31(50.8)$ & $20(32.8)$ \\
\hline Coccidiosis & $17(27.8)$ & $29(47.5)$ & $15(24.6)$ \\
\hline $\mathrm{PCV}^{\mathrm{C}}$ & $47(77)$ & $7(11.5)$ & $7(11.5)$ \\
\hline Meningitis & 32 (52.5) & $17(27.8)$ & $12(19.7)$ \\
\hline Dysentery & $6(9.8)$ & $44(72.2)$ & $11(18)$ \\
\hline E. coli diarrhea & $40(67.8)$ & $10(16.9)$ & 9 (15.3) \\
\hline Ileitis & $17(27.8)$ & $22(36.1)$ & $22(36.1)$ \\
\hline Mange & $12(19.7)$ & $37(60.6)$ & $12(19.7)$ \\
\hline \multicolumn{2}{|l|}{ Disease complexes } & $\begin{array}{l}\text { No. herds } \\
\text { (\%) Yes }\end{array}$ & $\begin{array}{l}\text { No. herds (\%) } \\
\text { No }\end{array}$ \\
\hline \multicolumn{2}{|c|}{$\begin{array}{l}\text { Respiratory complex } \\
\text { (PPRRS|APP|Enzootic pneumonia|Glasser) }\end{array}$} & $50(81.2)$ & $11(18.8)$ \\
\hline \multicolumn{2}{|c|}{$\begin{array}{l}\text { Enteric complex (Dysentery|E. coli } \\
\text { diarrhea|lleitis) }\end{array}$} & $49(80.3)$ & $12(19.7)$ \\
\hline Protocol & Weaning & Growing & Finishing \\
\hline \multicolumn{4}{|l|}{ CLEANING PROTOCOLS } \\
\hline No washing & $1(1.7)$ & $8(17)$ & $14(23)$ \\
\hline Pressurized water & $8(13.1)$ & $2(4.3)$ & $14(23)$ \\
\hline Detergent & $2(3.4)$ & $2(4.3)$ & $3(4.9)$ \\
\hline Disinfectant & $9(14.8)$ & $8(17)$ & $6(9.8)$ \\
\hline Dry & $10(17.2)$ & $6(12.8)$ & $7(11.5)$ \\
\hline Desiccant & $6(10.3)$ & 5 (10.6) & $3(4.9)$ \\
\hline Pressure water + disinfection & $15(25.9)$ & $10(21.2)$ & $8(13.1)$ \\
\hline Water + disinfection + dry & $4(6.9)$ & $4(8.6)$ & $4(6.6)$ \\
\hline Water + desiccant & $1(1.7)$ & $2(4.3)$ & $1(1.6)$ \\
\hline Water + dry + desiccant & $3(5.1)$ & 0 & $1(1.6)$ \\
\hline
\end{tabular}

${ }^{a}$ Not all questions were answered in all herds, thus not all questions sum 61 farms. ${ }^{b}$ Porcine respiratory and reproductive syndrome.

${ }^{c}$ PCV2, Porcine Circovirus2.

selected from the univariate analysis with a $P$-value $<0.25$ (Table 2).

Collinearity was observed among related variables (Supplementary Table 1). For example, strong collinearity was observed for type of feed (pelleted or meal) in different production stages and feed delivery (dry or liquid feeding) as well as source of feed (home produced or purchased) and feed delivery where all home-produced feed was fed as meal. Similarly, collinearity was observed among variables related to washing protocols. Other variables with collinearity were chlorinated water, turnover of staff in the last 2 years or change of clothes by visitors (Table 4 ). 
TABLE 4 | Variables associated with Salmonella using a relaxed $p$-value $(P<0.25)$ from univariable mixed linear regression of meat juice ELISA herd prevalence results obtained from slaughtered pigs during 2014

\begin{tabular}{|c|c|c|c|}
\hline Potential factor indicator & Level & Estimate $^{1}$ & $P$-value \\
\hline Staff change $\mathrm{a}^{*}$ & $\begin{array}{l}\text { Yes } \\
\text { No }\end{array}$ & $\begin{array}{c}0 \\
-5.968\end{array}$ & 0.246 \\
\hline Training course $\mathrm{b}^{\mathrm{b}^{*}, \mathrm{k}}$ & $\begin{array}{l}\text { Yes } \\
\text { No }\end{array}$ & $\begin{array}{c}0 \\
-8.674\end{array}$ & 0.069 \\
\hline $\begin{array}{l}\text { Origin of weaned pig } \\
\text { feed }^{a, c^{\star}}\end{array}$ & $\begin{array}{l}\text { Home produced } \\
\text { Purchased }\end{array}$ & $\begin{array}{c}-11.963 \\
0\end{array}$ & 0.05 \\
\hline $\begin{array}{l}\text { Origin of growing pig feed } \\
a, c^{*}\end{array}$ & $\begin{array}{l}\text { Home produced } \\
\text { Purchased }\end{array}$ & $\begin{array}{c}-9.955 \\
0\end{array}$ & 0.088 \\
\hline $\begin{array}{l}\text { Origin of finishing pig } \\
\text { feed }^{a, c^{*}}\end{array}$ & $\begin{array}{l}\text { Home produced } \\
\text { Purchased }\end{array}$ & $\begin{array}{c}-0.991 \\
0\end{array}$ & 0.078 \\
\hline Type feed-sows ${ }^{a, c^{\star}, g}$ & $\begin{array}{l}\text { Liquid feed } \\
\text { Meal } \\
\text { Pelleted }\end{array}$ & $\begin{array}{c}-14.465 \\
-22.552 \\
0\end{array}$ & 0.233 \\
\hline $\begin{array}{l}\text { Type feed-weaned } \\
\text { pigs }^{a, c^{\star}, g}\end{array}$ & $\begin{array}{l}\text { Liquid feed } \\
\text { Meal } \\
\text { Pelleted }\end{array}$ & $\begin{array}{c}-15.215 \\
-11.092 \\
0\end{array}$ & 0.065 \\
\hline Type feed-finishing pigs ${ }^{\mathrm{C}^{\star}}$ & $\begin{array}{l}\text { Liquid feed } \\
\text { Meal } \\
\text { Pelleted }\end{array}$ & $\begin{array}{c}-14.864 \\
-8.423 \\
0\end{array}$ & 0.13 \\
\hline $\begin{array}{l}\text { Dry or wet feed for weaned } \\
\text { pigs }^{c^{*}}\end{array}$ & $\begin{array}{l}\text { Dry } \\
\text { Wet }\end{array}$ & $\begin{array}{c}8.848 \\
0\end{array}$ & 0.084 \\
\hline $\begin{array}{l}\text { Dry or wet feed for growing } \\
\text { pigs }^{c^{\star}, d, g}\end{array}$ & $\begin{array}{l}\text { Dry } \\
\text { Wet }\end{array}$ & $\begin{array}{c}8.471 \\
0\end{array}$ & 0.127 \\
\hline $\begin{array}{l}\text { Dry or wet feed for finishing } \\
\text { pigs }{ }^{\star} \text {, }\end{array}$ & $\begin{array}{l}\text { Dry } \\
\text { Wet }\end{array}$ & $\begin{array}{c}7.877 \\
0\end{array}$ & 0.146 \\
\hline Use of whey in finishers & $\begin{array}{l}\text { Yes } \\
\text { No }\end{array}$ & 0 & 0.238 \\
\hline 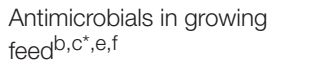 & $\begin{array}{l}\text { Yes } \\
\text { No }\end{array}$ & 8.892 & 0.123 \\
\hline Zinc in growing pig feed $\mathrm{C}^{\star}, \mathrm{g}$ & $\begin{array}{l}\text { Yes } \\
\text { No }\end{array}$ & $\begin{array}{c}0 \\
-6.189\end{array}$ & 0.212 \\
\hline Acids in finishing pig feed ${ }^{d, e}$ & $\begin{array}{l}\text { Yes } \\
\text { No }\end{array}$ & $\begin{array}{c}0 \\
-9.833\end{array}$ & 0.167 \\
\hline Water supplyg, & $\begin{array}{l}\text { Bore hole } \\
\text { Main supply } \\
\text { River } \\
\text { Other }\end{array}$ & $\begin{array}{c}-14.175 \\
-4 \text { to } 348 \\
-3.475 \\
0\end{array}$ & 0.244 \\
\hline Chlorinate water $\mathrm{g}^{*}$ & $\begin{array}{l}\text { Yes } \\
\text { No }\end{array}$ & $\begin{array}{c}-12.524 \\
0\end{array}$ & 0.072 \\
\hline Last analysis of water quality & (Months) & - & 0.2493 \\
\hline $\begin{array}{l}\text { Presence of perimeter } \\
\text { fence }^{f}\end{array}$ & $\begin{array}{l}\text { No } \\
\text { Single } \\
\text { Double }\end{array}$ & $\begin{array}{c}4.738 \\
13.637 \\
0\end{array}$ & 0.0821 \\
\hline Carcass disposal truck $\mathrm{h}^{\mathrm{h}^{*}}$ & $\begin{array}{l}\text { Outside } \\
\text { Inside }\end{array}$ & $\begin{array}{c}-10.758 \\
0\end{array}$ & 0.0252 \\
\hline Feed truck ${ }^{i^{*}}$ & $\begin{array}{l}\text { Outside } \\
\text { Inside }\end{array}$ & $\begin{array}{c}-9.195 \\
0\end{array}$ & 0.1167 \\
\hline $\begin{array}{l}\text { Cleaning including } \\
\text { disinfection and drying at } \\
\text { growing }\end{array}$ & $\begin{array}{l}\text { Yes } \\
\text { No }\end{array}$ & $\begin{array}{c}0 \\
-6.711\end{array}$ & 0.243 \\
\hline $\begin{array}{l}\text { Cleaning including } \\
\text { pressurized water at } \\
\text { finishing }\end{array}$ & $\begin{array}{l}\text { Yes } \\
\text { No }\end{array}$ & $\begin{array}{c}0 \\
6.617\end{array}$ & 0.149 \\
\hline $\begin{array}{l}\text { Cleaning including } \\
\text { disinfection at finishing }\end{array}$ & $\begin{array}{l}\text { Yes } \\
\text { No }\end{array}$ & $\begin{array}{c}0 \\
6.930\end{array}$ & 0.168 \\
\hline
\end{tabular}

(Continued)
TABLE 4 | Continued

\begin{tabular}{|c|c|c|c|}
\hline Potential factor indicator & Level & Estimate $^{1}$ & $P$-value \\
\hline Change of boots by staff ${ }^{k}$ & $\begin{array}{l}\text { Yes } \\
\text { No }\end{array}$ & $\begin{array}{c}0 \\
9.427\end{array}$ & 0.163 \\
\hline $\begin{array}{l}\text { Change of boots by } \\
\text { visitors } \mathrm{k}^{\mathrm{h}, \mathrm{k}^{*}}\end{array}$ & $\begin{array}{l}\text { Yes } \\
\text { No }\end{array}$ & $\begin{array}{c}0 \\
8.037\end{array}$ & 0.215 \\
\hline Presence of cats & $\begin{array}{l}\text { Yes } \\
\text { No }\end{array}$ & $\begin{array}{c}0 \\
-8.628\end{array}$ & 0.071 \\
\hline Presence of birds ${ }^{h}$ & $\begin{array}{l}\text { Yes } \\
\text { No }\end{array}$ & $\begin{array}{c}0 \\
-5.376\end{array}$ & 0.243 \\
\hline Glasser's disease $^{\text {h }}$ & $\begin{array}{l}\text { Yes } \\
\text { No } \\
\text { Unknown }\end{array}$ & $\begin{array}{c}12.628 \\
0 \\
-1.0801\end{array}$ & 0.051 \\
\hline Coccidia present ${ }^{i}$ & $\begin{array}{l}\text { Yes } \\
\text { No } \\
\text { Unknown }\end{array}$ & $\begin{array}{c}6.394 \\
11.906 \\
0\end{array}$ & 0.128 \\
\hline Swine Dysentery disease & $\begin{array}{l}\text { Yes } \\
\text { No } \\
\text { Unknown }\end{array}$ & $\begin{array}{c}20.811 \\
6.128 \\
0\end{array}$ & 0.078 \\
\hline E. colil Diarrhea & $\begin{array}{l}\text { Yes } \\
\text { No } \\
\text { Unknown }\end{array}$ & $\begin{array}{c}7.522 \\
-4.861 \\
0\end{array}$ & 0.055 \\
\hline Mange ${ }^{i}$ & $\begin{array}{l}\text { Yes } \\
\text { No } \\
\text { Unknown }\end{array}$ & $\begin{array}{c}-1.655 \\
7.6833 \\
0\end{array}$ & 0.212 \\
\hline Respiratory complex' & $\begin{array}{l}\text { Yes } \\
\text { No }\end{array}$ & $\begin{array}{c}0 \\
-9.330\end{array}$ & 0.147 \\
\hline
\end{tabular}

${ }^{1}$ Estimate defines the influence of variable levels in the seroprevalence of Salmonella within the herd.

${ }^{a-l}$ Collinearity among selected variables.

${ }^{*}$ Denotes collinearity among the variable with all others with the same letter.

Twenty-one variables were included in the multivariate analysis (Table 4). Nine of these variables were retained in the model (Figure 1). Within the feed variables analyzed, farms using home-produced feed were associated to lower seroprevalence compared to those using purchased feed (estimate $=-8.42$; $\mathrm{SE}=4.9 ; p=0.042$ ). Among biosecurity factors, banning the feed truck access to the farmyard (estimate $=-10.06$; $\mathrm{SE}=4.42 ; p=0.048)$, or the absence of cats on the farm (estimate $=10.3 ; \mathrm{SE}=5.57 ; p=0.02$ ), exhibited a protective effect to Salmonella seroprevalence, while the lack of internal policy to change boots (estimate $=18.05$; SE $=$ $6.00 ; p=0.014$ ), and the lack of perimeter fence (estimate $=$ 13.99; $\mathrm{SE}=5.57 ; p=0.051$ ) were significantly associated to Salmonella seroprevalence. Among management factors, those farms without staff turnover within the last 2 years had lower seroprevalence values (estimate $=-10.73 ; \mathrm{SE}=4.28 ; p=0.042$ ), while those farms without introducing people into training were significantly associated to lower seroprevalence (estimate $=-13.34 ; \mathrm{SE}=4.09 ; p=0.045)$. Finally, two diseases were significantly linked to Salmonella seroprevalence. Farms with swine dysentery (Brachyspira hyodysenteriae) were shown to be increased in their Salmonella levels (estimate $=17.02$; $\mathrm{SE}=7.13$; $p=0.044$ ) and we also observed a trend for those farms with E. coli diarrhea problems (estimate $=10.65$; $\mathrm{SE}=5.72 ; p=$ 0.1 . None of the interactions among these nine variables was significant. 


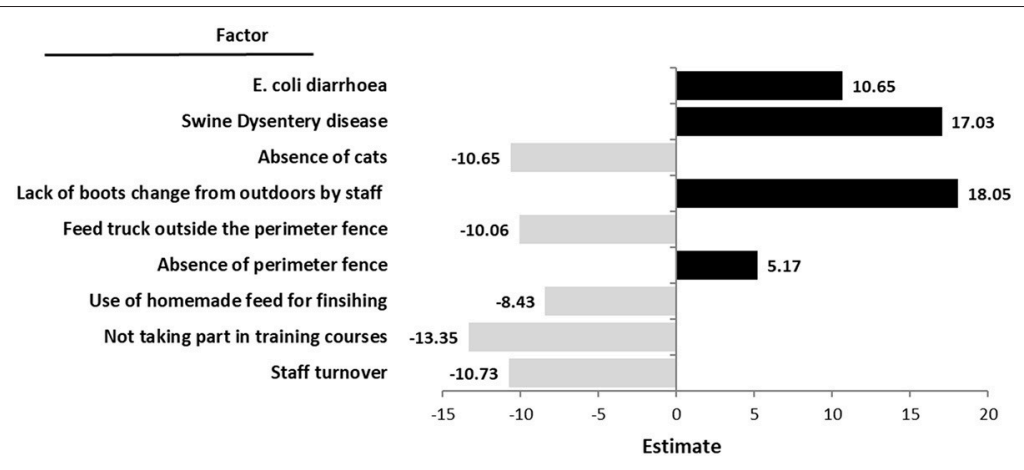

FIGURE 1 | Multivariable mixed linear regression of Salmonella sero-prevalence as measured by meat juice ELISA from slaughtered pigs in 61 Irish herds.

\section{DISCUSSION}

Among zoonotic pathogens affecting swine, Salmonella is the first pathogen associated to human gastroenteritis linked to pork consumption (EFSA, 2015). Pork is ranked as the third most common source of human salmonellosis, but it is at present considered the main source of Salmonella from meat in countries where Salmonella control in poultry and laying hens has been successful (De Knegt et al., 2015). Salmonella control programmes in pig production aim to reduce the burden of Salmonella in pork meat. Most of the control programmes include surveillance of the herd status by monitoring the presence of antibodies against Salmonella in finishing pigs at market weight (Quirke et al., 2001; Alban et al., 2012). The information garnered from surveillance programmes can be used to categorize herds by risk, but also offers the opportunity to explore the epidemiology and control of the infection (Baptista et al., 2009, 2011; Smith et al., 2010). The present study combining available serological data from the NPSCP database (used as continuous outcome variable) with information gathered through a questionnaire, provided an opportunity to evaluate Salmonella risk factors in Irish pig herds. Indirect detection of Salmonella, based on the detection of antibodies in the host, offers a number of advantages compared to analysis performed by bacteriology. The fact that antibodies can be detected for long periods of time (Funk et al., 2001) overcomes the problem of the intermittent shedding of Salmonella in feces (Beloeil et al., 2003). The surveillance data also offers a huge advantage compared to cross-sectional studies in that the analysis of samples throughout a period of 12 months, allows the level of infection in the herd to be estimated with much more accuracy compared to single values in cross-sectional studies where temporary or seasonal changes may skew the data (Hautekiet et al., 2008). A potential limitation of using surveillance data is the limited number of sera tested per month compared to the number of slaughtered pigs, fact that biases the actual herd prevalence (Nielsen et al., 1998) but with enough power to estimate annual herd prevalence (Alban et al., 2012).

There is vast information in the literature regarding on-farm Salmonella risk factors (van der Wolf et al., 2001a,b; Beloeil et al., 2003, 2007; Lo Fo Wong et al., 2004; García-Feliz et al., 2009; Correia-Gomes et al., 2012, 2013). These studies are useful in identifying important factors related to herd characteristics, management, husbandry, hygiene/health that may help prevent or mitigate infection. Conflicting results between studies can be related to particularities of the production system in different countries or by limitations in studies where all factors associated with the infection were not explored. Sixty-one herds were included in the analysis for the present study, which is $~ 20 \%$ of the commercial pig herds in the Republic of Ireland. The number, a good representation of the Irish herds yielded nevertheless a scarce number of surveys compared to previous studies (Kranker et al., 2001; Nollet et al., 2004; García-Feliz et al., 2009) limiting the power of the analysis. To maximize the information gained by the questionnaire, 125 variables were identified from the 33 questions in the survey and of these, nine were retained in the final regression model.

Although feed can be source of Salmonella infection (Burns et al., 2015), different studies, including numerous risk factor studies, have also shown that feed form and method of delivery can be used to mitigate Salmonella on farm (Mikkelsen et al., 2004; García-Feliz et al., 2009). In agreement with Kranker et al. (2001), the present study found that herds with their own feed mill (home-produced feed) had a lower Salmonella prevalence compared to herds purchasing feed. This result is not consequence of the origin of feed but related to the feed presentation (meal or pelleted). Home-made/purchase was included in the model as there were less interactions with other variables compared to meal/pelleted feed variable. All farms with home produced feed, fed meal diets while those purchasing feed were more likely to use pelleted feed. Non-pelleted feed is linked with slower gastric transit time together with a more viscous, porridge-like consistency in the stomach, both of which favor increased microbial fermentation in the stomach (Mikkelsen et al., 2004). Moreover, coarsely-ground meal may not be as well digested as finely ground pelleted feed at the terminal ileum leaving additional carbohydrate substrate to be fermented in the large intestine (Mikkelsen et al., 2004). As a consequence, the growth of lactic acid-producing microbiota is promoted and the concentration of volatile fatty acids is increased, creating a hostile environment for Salmonella (low $\mathrm{pH}$, organic acids, competitive 
exclusion etc.) in the lower gastrointestinal tract (Arguello et al., 2013a).

Factors related to herd characteristics such as herd size, management, and husbandry have been linked with Salmonella infection by different studies (Kranker et al., 2001; Vico et al., 2001; Beloeil et al., 2003, 2004; Leontides et al., 2003). Allin/all-out (AIAO) flow disrupts the transmission of infection between production stages (Beloeil et al., 2004; Farzan et al., 2010). However, similar to some other studies (Nollet et al., 2004; Rajić et al., 2007; García-Feliz et al., 2009) our study found no benefit in terms of Salmonella mitigation on farms using $\mathrm{AI} / \mathrm{AO}$ in weaners, growers and finishers. This may be related to the fact that in most instances $\mathrm{AI} / \mathrm{AO}$ was by room rather than by building as in other studies which is likely to have decreased the effectiveness of the intervention in the current study. Similarly, no potential benefit was demonstrated where cleaning and disinfection protocols were implemented between batches. Nine variables were generated from the survey (Table 1) to analyse the effect of different protocols used (pressurized water, detergent, disinfectant and desiccation) or their combinations. None of them were significant in the final model. As with $\mathrm{AI} / \mathrm{AO}$, a reduction in Salmonella level would be expected when cleaning protocols are implemented on the farm. However, despite some studies having shown this to be the case (Funk and Gebreyes, 2004), others could not link implementation of cleaning protocols to a decrease in Salmonella (Nollet et al., 2004). A possible explanation is that effective cleaning protocols are not correctly performed on farm (Mannion et al., 2007). Among the management and husbandry factors included in the questionnaire, there was a trend for those herds that did not change staff in the previous 2 years to have lower Salmonella levels than those where staff turnover was high. This result may be associated with the standard of husbandry on farms, with the possibility of poorer standards on farms with inexperienced staff where staff turnover is highest. Attendance at courses and workshops was linked to a higher prevalence, although we are skeptical of the validity of this result and believe that the question should be revised for further such surveys.

Biosecurity is an essential component in the control of Salmonella; external biosecurity decreases the likelihood of introducing Salmonella into the herd while internal biosecurity reduces the spread of the infection between stages and batches of pigs (FAO, 2015). The presence of a perimeter fence around the unit and restricting the access of feed trucks to outside the farm yard perimeter from which the feed bins were accessed were two factors linked with a reduced Salmonella prevalence in the present study. Similarly, one aspect of internal biosecurity, the change of footwear from outside the unit to inside, was also linked to reduced Salmonella prevalence. In addition, the presence of cats on the unit was linked to higher levels of Salmonella which agrees with the results of Nollet et al. (2004). Rodents (Vico et al., 2001) were frequently observed in Irish herds in the present study $(83.6 \%$ of the farmers admitted to seeing rodents on their farms). Cats may help to control rodent populations (Funk et al., 2001) but are themselves a vector for Salmonella.

Swine salmonellosis is usually a subclinical infection (Boyen et al., 2008) but severity of infection may be increased by the presence of other infections in the herd. Previous studies have linked the presence of Salmonella to other diseases such as PRRS (Beloeil et al., 2007). In the present study we allocated a complete section of the questionnaire to herd health, as we considered that co-infections could be one of the key factors in the perpetuation of the infection over a prolonged period (defined as high prevalence at the end of the year). Our survey included a list of common swine infections, including respiratory, intestinal, and systemic diseases and farmers were instructed to be as precise as possible when indicating the presence or absence of these diseases. Furthermore, questions regarding the vaccination programme used were included in order to gain insight on the pathogens potentially circulating within the herd and their prevention.

Two intestinal disorders were found to be associated with Salmonella: swine dysentery and E. coli diarrhea. Swine dysentery, a haemorrhagic diarrhea caused by Brachyspira hyodysenteriae affects pigs in the growing and/or finishing stages, causing considerable economic losses (Alvarez-Ordóñez et al., 2013). In contrast, E. coli diarrhea usually occurs during the suckling or post-weaning periods depending on the pathotype of $E$. coli involved. The strong association between high Salmonella prevalence and swine dysentery and the trend toward an association with $E$. coli diarrhea demonstrates the importance of controlling concomitant enteric infections in any Salmonella control programme. For example, Walia et al. (2016) attributed the lack of efficacy of an organic acid-based feed additive in controlling Salmonella in finishers to the presence of a concomitant Lawsonia intracellularis infection (porcine proliferative enteropathy or PPE) and van der Wolf et al. (2001a) linked herds with diarrhea (cause not specified) to presence of Salmonella. Intestinal disorders alter the physiological conditions of the gut favoring the development of other pathologies, making it common to find several pathogens during laboratory diagnosis of diarrhea cases (Williamson et al., 2015). The four intestinal pathogens (Brachyspira spp., Lawnonia intracellularis, E. coli, and Salmonella) constitute the basis of the "intestinal complex." We failed to demonstrate an association between Salmonella prevalence and the variable "intestinal complex" which included any of the three other intestinal diseases mentioned above. A potential reason why Salmonella and L. intracellularis were not linked in the present study despite other studies having associated both pathologies (Borewicz et al., 2015; Walia et al., 2016), is that PPE often causes subclinical disease and farmers may not have been aware of the presence of the pathogen in their herds. However, the fact that two intestinal infectious disorders could be linked to Salmonella once again demonstrates the importance of a multifaceted approach in a successful Salmonella control programme.

The present study shows the value of surveillance data in uncovering factors associated with on-farm Salmonella infection. Feed form (use of meal vs. pelleted) appears to be a useful strategy to mitigate the burden of on-farm Salmonella. Biosecurity factors such as perimeter fencing, changing of footwear between outside and inside of the unit and the absence of cats were associated with lower Salmonella sero-prevalence, while intestinal diseases (swine dysentery and E. coli diarrhea) were linked to higher Salmonella sero-prevalence. These results show that Salmonella 
infection in pigs is multi-factorial and highlight that for its control different strategies must be included simultaneously.

\section{AUTHORS CONTRIBUTIONS}

HA, EM, FL, JE and GD participated in the design of the study. GD, FL, GG and PL provided the funding to perform the study. $\mathrm{HA}, \mathrm{KW}$ and HL collected the questionnaire data. KW, HL and JE provided the surveillance data. HA, EM, GG and PL performed the analysis of the data. HA, EM, FL, GD, GG and PL wrote the manuscript. All authors approved the final version of the manuscript.

\section{FUNDING}

This study was funded by the Food Institutional Research Measure (FIRM) administered by the Department of Agriculture

\section{REFERENCES}

Alban, L., Baptista, F. M., Møgelmose, V., Sørensen, L. L., Christensen, H., Aabo, S., et al. (2012). Salmonella surveillance and control for finisher pigs and pork in Denmark-A case study. Food Res. Int. 45, 656-665. doi: 10.1016/j.foodres.2011.02.050

Alvarez-Ordóñez, A., Martínez-Lobo, F. J., Arguello, H., Carvajal, A., and Rubio, P. (2013). Swine dysentery: aetiology, pathogenicity, determinants of transmission and the fight against the disease. Int. J. Environ. Res. Public Health 10, 1927-1947. doi: 10.3390/ijerph10051927

Arguello, H., Carvajal, A., Costillas, S., and Rubio, P. (2013a). Effect of the addition of organic acids in drinking water or feed during part of the finishing period on the prevalence of Salmonella in finishing pigs. Foodborne Pathog. Dis. 10, 842-849. doi: 10.1089/fpd.2013.1497

Arguello, H., Carvajal, A., Naharro, G., and Rubio, P. (2013b). Evaluation of protection conferred by a Salmonella Typhimurium inactivated vaccine in Salmonella-infected finishing pig farms. Comp. Immunol. Microbiol. Infect. Dis. 36, 489-498. doi: 10.1016/j.cimid.2013.05.002

Baptista, F. M., Alban, L., Ersbøll, A. K., and Nielsen, L. R. (2009). Factors affecting persistence of high Salmonella serology in Danish pig herds. Prev. Vet. Med. 92, 301-308. doi: 10.1016/j.prevetmed.2009.08.005

Baptista, F. M., Alban, L., Nielsen, L. R., Domingos, I., Pomba, C., and Almeida, V. (2010). Use of herd information for predicting Salmonella status in pig herds. Zoonoses Public Health 57, 49-59. doi: 10.1111/j.1863-2378.2010.01354.x

Baptista, F. M., Halasa, T., Alban, L., and Nielsen, L. R. (2011). Modelling food safety and economic consequences of surveillance and control strategies for Salmonella in pigs and pork. Epidemiol. Infect. 139, 754-764. doi: $10.1017 /$ S0950268810001767

Beloeil, P. A., Chauvin, C., Proux, K., Fablet, C., Madec, F., and Alioum, A. (2007). Risk factors for Salmonella seroconversion of fattening pigs in farrow-to-finish herds. Vet. Res. 38, 835-848. doi: 10.1051/vetres:2007034

Beloeil, P. A., Chauvin, C., Proux, K., Rose, N., Queguiner, S., Eveno, E., et al. (2003). Longitudinal serological responses to Salmonella enterica of growing pigs in a subclinically infected herd. Prev. Vet. Med. 60, 207-226. doi: 10.1016/S0167-5877(03)00126-0

Beloeil, P. A., Fravalo, P., Fablet, C., Jolly, J. P., Eveno, E., Hascoet, Y., et al. (2004). Risk factors for Salmonella enterica subsp. enterica shedding by marketage pigs in French farrow-to-finish herds. Prev. Vet. Med. 63, 103-120. doi: 10.1016/j.prevetmed.2004.01.010

Borewicz, K. A., Kim, H. B., Singer, R. S., Gebhart, C. J., Sreevatsan, S., Johnson, T., et al. (2015). Changes in the porcine intestinal microbiome in response to infection with Salmonella enterica and Lawsonia intracellularis. PLoS ONE 10:e0139106. doi: 10.1371/journal.pone.0139106
Food and the Marine (DAFM) (FIRM/RSF/CoFoRD 2011 Project $11 / \mathrm{SF} / 329)$.

\section{ACKNOWLEDGMENTS}

The authors gratefully acknowledge the staff at Longtown Research Farm and the Central Veterinary Research Laboratory (CVRL) Backweston for their expert help in the serological analyses of the study.

\section{SUPPLEMENTARY MATERIAL}

The Supplementary Material for this article can be found online at: https://www.frontiersin.org/articles/10.3389/fmicb. 2018.00187/full\#supplementary-material

Supplementary Table 1 | Collinearity results among selected variables from the univariate analysis in the Salmonella risk factors study conducted in 61 Irish farrow-to-finish herds.

Boyen, F., Haesebrouck, F., Maes, D., Van Immerseel, F., Ducatelle, R., and Pasmans, F. (2008). Non-typhoidal Salmonella infections in pigs: a closer look at epidemiology, pathogenesis and control. Vet. Microbiol. 130, 1-19. doi: 10.1016/j.vetmic.2007.12.017

Burns, A. M., Lawlor, P. G., Gardiner, G. E., McCabe, E. M., Walsh, D., Mohammed, M., et al. (2015). Salmonella occurrence and Enterobacteriaceae counts in pig feed ingredients and compound feed from feed mills in Ireland. Prev. Vet. Med. 121, 231-239. doi: 10.1016/j.prevetmed.2015.07.002

Correia-Gomes, C., Economou, T., Mendonça, D., Vieira-Pinto, M., and NizaRibeiro, J. (2012). Assessing risk profiles for Salmonella serotypes in breeding pig operations in Portugal using a Bayesian hierarchical model. BMC Vet. Res. 8:226. doi: 10.1186/1746-6148-8-226

Correia-Gomes, C., Mendonça, D., Vieira-Pinto, M., and Niza-Ribeiro,. J. (2013). Risk factors for Salmonella spp in Portuguese breeding pigs using a multilevel analysis. Prev. Vet. Med. 108, 159-166. doi: 10.1016/j.prevetmed.2012.07.013

De Busser, E. V., De Zutter, L., Dewulf, J., Houf, K., and Maes, D. (2013). Salmonella control in live pigs and at slaughter. Vet. J. 196, 20-27. doi: 10.1016/j.tvjl.2013.01.002

De Knegt, L. V., Pires, S. M., and Hald, T. (2015). Attributing foodborne salmonellosis in humans to animal reservoirs in the European Union using a multi-country stochastic model. Epidemiol. Infect. 143, 1175-1186. doi: 10.1017/S0950268814001903

De Ridder, L., Maes, D., Dewulf, J., Pasmans, F., Boyen, F., Haesebrouck, F., et al. (2013). Evaluation of three intervention strategies to reduce the transmission of Salmonella Typhimurium in pigs. Vet. J. 197, 613-618. doi: 10.1016/j.tvjl.2013.03.026

European Food Safety Authority (EFSA) (2015). The European union summary report on trends and sources of zoonoses, zoonotic agents and food-borne outbreaks in 2013. EFSA J. 13:3991. doi: 10.2903/j.efsa.2015.3991

Farzan, A., Friendship, R. M., Dewey, C. E., Poppe, C., and Funk, J. (2010). Evaluation of the risk factors for shedding Salmonella with or without antimicrobial resistance in swine using multinomial regression method. Zoonoses Public Health 57, 85-93. doi: 10.1111/j.1863-2378.2010.01357.x

FAO (2015). Interventions for the Control of Nontyphoidal Salmonella spp. in Beef and Pork. Available online at: www.codexalimentarius.org

Funk, J., and Gebreyes, W. A. (2004). Risk factors associated with Salmonella prevalence on swine farms. Swine Health Prod. 12, 246-251.

Funk, J. A., Davies, P. R., and Nichols, M. A. (2001). Longitudinal study of Salmonella enterica in growing pigs reared in multiple-site swine production systems. Vet. Microbiol. 83, 45-60. doi: 10.1016/S0378-1135(01)00404-7

García-Feliz, C., Carvajal, A., Collazos, J. A., and Rubio, P. (2009). Herd-level risk factors for faecal shedding of Salmonella enterica in Spanish fattening pigs. Prev. Vet. Med. 91, 130-136. doi: 10.1016/j.prevetmed.2009.05.011 
Hautekiet, V., Geert, V., Marc, V., and Rony, G. (2008). Development of a sanitary risk index for Salmonella seroprevalence in Belgian pig farms. Prev. Vet. Med. 86, 75-92. doi: 10.1016/j.prevetmed.2008.03.005

Kranker, S., Dahl, J., and Wingstrand, A. (2001). Bacteriological and serological examination and risk factor analysis of Salmonella occurrence in sow herds, including risk factors for high Salmonella seroprevalence in receiver finishing herds. Berl. Munch. Tierarztl. Wochenschr. 114, 350-352.

Leontides, L. S., Grafanakis, E., and Genigeorgis, C. (2003). Factors associated with the serological prevalence of Salmonella enterica in Greek finishing swineherds. Epidemiol. Infect. 131, 599-606. doi: 10.1017/S0950268803008732

Lo Fo Wong, D. M. A., Dahl, J., Stege, H., van der Wolf, P. J., Leontides, L., von Altrock, A., et al. (2004). Herd-level risk factors for subclinical Salmonella infection in European finishing-pig herds. Prev. Vet. Med. 62, 253-266. doi: 10.1016/j.prevetmed.2004.01.001

Mannion, C., Leonard, F. C., Lynch, P. B., and Egan, J. (2007). Efficacy of cleaning and disinfection on pig farms in Ireland. Vet. Rec. 161, 371-375. doi: $10.1136 / v r .161 .11 .371$

Mikkelsen, L. L., Naughton, P. J., Hedemann, M. S., and Jensen, B. B. (2004). Effects of physical properties of feed on microbial ecology and survival of Salmonella enterica serovar Typhimurium in the pig gastrointestinal tract. Appl. Environ. Microbiol. 70, 3485-3492. doi: 10.1128/AEM.70.6.34853492.2004

Nielsen, B., Ekeroth, L., Bager, F., and Lind, P. (1998). Use of muscle fluid as a source of antibodies for serologic detection of Salmonella infection in slaughter pig herds. J. Vet. Diagn. Invest. 10, 158-163. doi: 10.1177/104063879801000207

Nollet, N., Maes, D., De Zutter, L., Duchateau, L., Houf, K., Huysmans, K., et al. (2004). Risk factors for the herd-level bacteriologic prevalence of Salmonella in Belgian slaughter pigs. Prev. Vet. Med. 65, 63-75. doi: 10.1016/j.prevetmed.2004.06.009

Quirke, A. M., Leonard, N., Kelly, G., Egan, J., Lynch, P. B., Rowe, T., et al. (2001). Prevalence of Salmonella serotypes on pig carcasses from high- and low-risk herds slaughtered in three abattoirs. Berl. Munch. Tierarztl. Wochenschr. 114, 360-362.

Rajić, A., Chow, E. Y., Wu, J. T., Deckert, A. E., Reid-Smith, R., Manninen, K., et al. (2007). Salmonella infections in ninety Alberta swine finishing farms: serological prevalence, correlation between culture and serology, and risk factors for infection. Foodborne Pathog. Dis. 4, 169-177. doi: 10.1089/fpd.2006.0073

Smith, R. P., Clough, H. E., and Cook, A. J. (2010). Analysis of meat juice ELISA results and questionnaire data to investigate farm-level risk factors for Salmonella infection in UK pigs. Zoonoses Public Health 57, 39-48. doi: 10.1111/j.1863-2378.2010.01362.x

Stärk, K. D., Wingstrand, A., Dahl, J., Møgelmose, V., and Lo Fo Wong, D. M. (2002). Differences and similarities among experts' opinions on Salmonella enterica dynamics in swine pre-harvest. Prev. Vet. Med. 53, 7-20. doi: 10.1016/S0167-5877(01)00278-1

van der Wolf, P. J., Lo Fo Wong, D. M., Wolbers, W. B., Elbers, A. R., van der Heijden, H. M., van Schie, F. W., et al. (2001a). A longitudinal study of Salmonella enterica infections in high-and low-seroprevalence finishing swine herds in The Netherlands. Vet. Q. 23, 116-121. doi: 10.1080/01652176.2001.9695096

van der Wolf, P. J., Wolbers, W. B., Elbers, A. R., van der Heijden, H. M., Koppen, J. M., Hunneman, W. A., et al. (2001b). Herd level husbandry factors associated with the serological Salmonella prevalence in finishing pig herds in The Netherlands. Vet. Microbiol. 78, 205-219. doi: 10.1016/S0378-1135(00) 00294-7

Vico, J. P., Rol, I., Garrido, V., San Román, B., Grilló, M. J., and Mainar-Jaime, R. C. (2001). Salmonellosis in finishing pigs in Spain: prevalence, antimicrobial agent susceptibilities, and risk factor analysis. J. Food Prot. 74, 1070-1078. doi: 10.4315/0362-028X.JFP-10-515

Walia, K., Argüello, H., Lynch, H., Leonard, F. C., Grant, J., Yearsley, D., et al. (2016). Effect of feeding sodium butyrate in the late finishing period on Salmonella carriage, seroprevalence, and growth of finishing pigs. Prev. Vet. Med. 131, 79-86. doi: 10.1016/j.prevetmed.2016 07.009

Williamson, S., Robertson, S., Stringer, L., Smith, R., and Davies, R. (2015). "Salmonellosis in pigs: what does disease surveillance data from England-Wales tell us?," in Proceedings of Safepork 2015 (Porto), 97.

Conflict of Interest Statement: The authors declare that the research was conducted in the absence of any commercial or financial relationships that could be construed as a potential conflict of interest.

Copyright (c) 2018 Argüello, Manzanilla, Lynch, Walia, Leonard, Egan, Duffy, Gardiner and Lawlor. This is an open-access article distributed under the terms of the Creative Commons Attribution License (CC BY). The use, distribution or reproduction in other forums is permitted, provided the original author(s) and the copyright owner are credited and that the original publication in this journal is cited, in accordance with accepted academic practice. No use, distribution or reproduction is permitted which does not comply with these terms. 